\title{
Chlorine and the Chemistry of Disinfectants*
}

\author{
A Fascinating Journey-18th Century to the COVID Times
}

\section{N. Dastagiri Reddy and Anil J. Elias}

The onset of COVID-19 pandemic has suddenly rendered disinfectants an essential class of substances for daily use globally. The demand for different disinfectants has rapidly surged, and it is important that the users of disinfectants are aware of the chemicals present in them, their properties, and how these disinfectants were introduced for public use. The history and development of chlorine-containing disinfectants and their possible modes of action have been explained in this article. The development and current status of hypochlorite-based compounds and chlorinated phenol-based compounds as disinfectants are also discussed in detail. The article explores the pros and cons of having chlorine in disinfectants and also looks critically at the future of such disinfectants based on safety and environmental considerations.

\section{Introduction}

At a time when the whole world is facing the challenge of dealing with the COVID-19 pandemic, some simple chemicals, known from very early times, have assured humanity that they are exceptionally good at preventing the spread of this disease and protect those who are willing to use these chemicals. These are mainly: (a) the soap for washing hands, (b) alcohol (isopropyl and ethyl) as the main ingredient in hand sanitizers, and (c) a few chlorinebased disinfectants for destroying the virus. While the term 'disinfectant' refers to any compound that kills or destroys microorganisms on any surface, a similar word-antiseptic-refers to compounds that are applied to a wound or skin (living tissue)

${ }^{*}$ Vol.26, No.3, DOI: https://doi.org/10.1007/s12045-021-1135-y

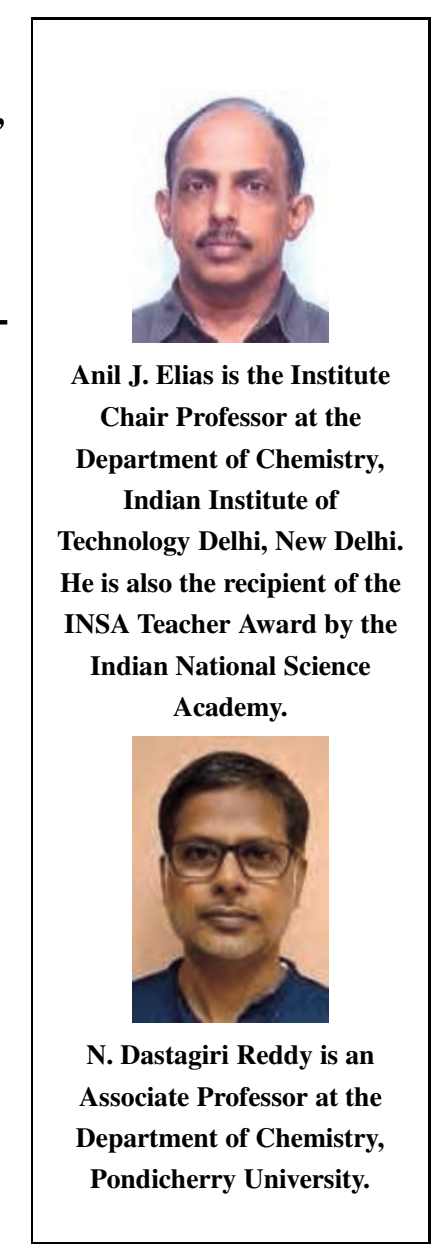

Keywords

Chlorine, disinfectants, hypochlorites, para-chloro-meta-xylenol, benzalkonium chloride, chlorhexidine. 
Figure 1. Chlorine-based disinfectants and water purification agents.
In daily household use, sodium hypochlorite is the major ingredient in Chlorox ${ }^{\circledR}$ brand

disinfectant products such as wipes and bleach

for clothes, Domex ${ }^{\circledR}$

floor cleaner, and Harpic ${ }^{\circledR}$ bathroom cleaner. Bleaching powder is sold generally as such, while PCMX, benzalkonium chloride, and chlorhexidine are the main germ-killing ingredients of Dettol ${ }^{\circledR}$ disinfectant solution, Lysol ${ }^{\circledR}$ disinfectant surface cleaner, and Savlon ${ }^{\circledR}$ disinfectant liquid, respectively.

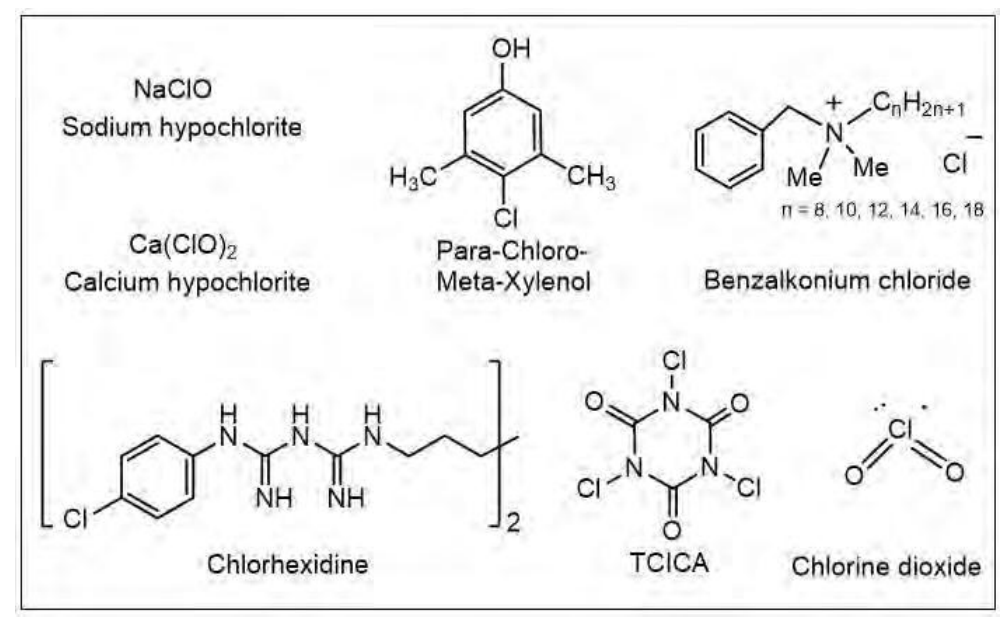

to prevent infection and putrefaction. Among the time-tested disinfectants and antiseptics, a few of those based on the element chlorine stand out truly as the most trustworthy, safe, effective, inexpensive, and free from side effects. These are sodium hypochlorite (bleach), calcium hypochlorite (bleaching powder), para-chloro-meta-xylenol (PCMX), benzalkonium chloride, and chlorhexidine (Figure 1). In daily household use, sodium hypochlorite is the major ingredient in Chlorox ${ }^{\circledR}$ brand disinfectant products such as wipes and bleach for clothes, Domex ${ }^{\circledR}$ floor cleaner, and Harpic ${ }^{\circledR}$ bathroom cleaner. Bleaching powder is sold generally as such, while PCMX, benzalkonium chloride, and chlorhexidine are the main germ-killing ingredients of Dettol ${ }^{\circledR}$ disinfectant solution, Lysol ${ }^{\circledR}$ disinfectant surface cleaner, and Savlon ${ }^{\circledR}$ disinfectant liquid, respectively. It is also to be mentioned that for water purification, chlorine gas is bubbled through water in water purification plants, and slow chlorine releasing tablets (e.g. trichloroisocyanuric acid, TCICA) are used for disinfecting swimming pools. A relatively new milder and safer replacement for chlorine gas, namely, chlorine dioxide $\left(\mathrm{ClO}_{2}\right)$ is also marketed for water purification. In this article, we detail the interesting history behind the development of some of these disinfectants, how they have stood the test of time, and are still the most sought after, especially at a time when people across the world have suddenly become aware of the need of disinfectants. 
Among all the halogens, chlorine is the highest industrially produced element in the world. There is nothing unusual about this as every kilogram of seawater has 35 grams of salts dissolved in it, and 55\% of this is chloride. All the oceans of the Earth together contain approximately $2.6 \times 10^{16}$ metric tonnes of chloride which makes it the most abundant ion present in seawater, not to mention significant amounts present on land as rocksalt [1]. Although around 65 million tonnes of chlorine gas is industrially produced from brine by electrolysis and ion exchange membrane separation methods, only $5 \%$ of this goes for water purification, and a much lesser amount for the production of disinfectants.

\section{Discovery of Chlorine Gas}

Let us see how it all started. Chemists of ancient days had only relatively few chemicals to play with, but they did have fun exploring the chemistry of those they could lay their hands on. The story begins with sulfuric acid, the mother of all mineral acids, known as early as $854 \mathrm{AD}$ as oil of vitriol and prepared for the first time by heating green vitriol $\left(\mathrm{FeSO}_{4} \cdot 7 \mathrm{H}_{2} \mathrm{O}\right)$. During the 17 th century, Johann Glauber, a German-Dutch chemist made sulfuric acid by burning sulfur with saltpeter [potassium nitrate crystallized from guano (dried bird excreta!)] while passing steam. As the saltpeter decomposed, it oxidized the $\mathrm{SO}_{2}$, formed on burning sulfur to $\mathrm{SO}_{3}$, which combined with the steam to produce sulfuric acid. The first large scale industrial production of sulfuric acid was made possible in 1736 by Joshua Ward, a British pharmacist. Although known from the 15th century (from the reaction of rock salt and green vitriol), hydrochloric acid was prepared on large scale by Johann Rudolph by reacting sulfuric acid with table salt. It was the Swedish chemist Carl Wilhelm Scheele who in 1774 made hydrochloric acid react with the well-known mineral pyrolusite $\left(\mathrm{MnO}_{2}\right)$ to make elemental chlorine as a pungent-smelling greenish-yellow gas (Figure 2). The gas itself has also got into history as the first chemical warfare agent introduced by none other than the Nobel winning Fritz Haber during the First World War [2]. The use of chlorine for bleaching clothes was discovered
Sulfuric acid, the mother of all mineral acids, was known as early as 854 $\mathrm{AD}$ as oil of vitriol and was prepared for the first time by heating green vitriol $\left(\mathrm{FeSO}_{4} \cdot 7 \mathrm{H}_{2} \mathrm{O}\right)$. During the 17 th century, Johann Glauber made sulfuric acid by burning sulfur with saltpeter while passing steam. 
Figure 2. Carl Wilhelm Scheele and his set up for chlorine gas synthesis.

\footnotetext{
${ }^{1}$ Similar to the 'goldbeater's skin', also prepared from animal intestines with which very thin $(1 \mu \mathrm{m})$ gold leaves were made.
}

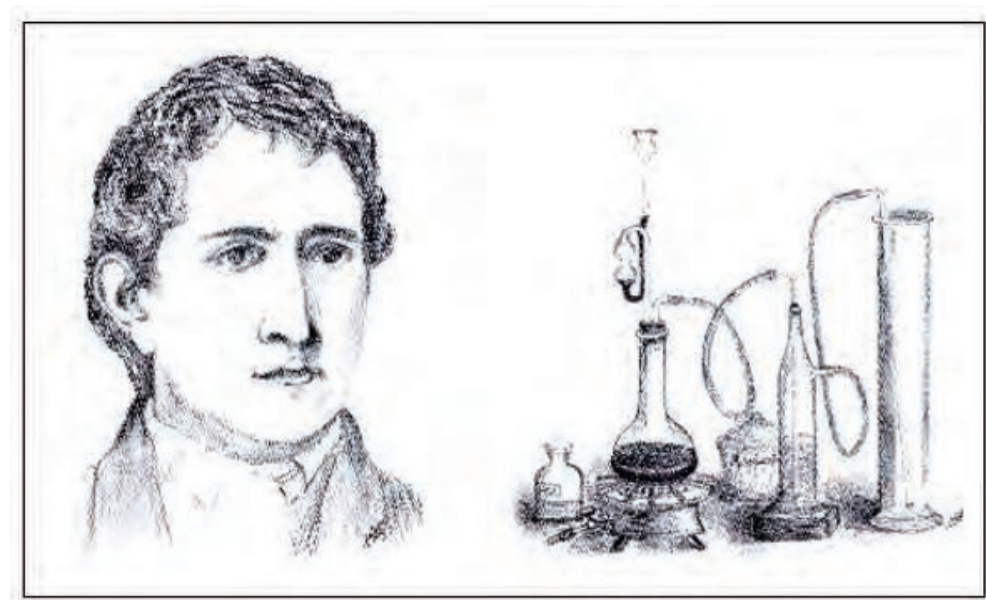

by the French chemist Claude Berthelot as early as 1785. Early scientists experimented reacting this pungent-smelling gas with many reagents and bubbling the gas through lye solutions $[\mathrm{NaOH}$, $\mathrm{KOH}$, and $\left.\mathrm{Ca}(\mathrm{OH})_{2}\right]$ resulted in the discovery of the hypochlorites.

Chlorine has the unusual property that it shows variable oxidation states from -1 to +7 in its compounds. Many of the anionic and neutral oxides of chlorine are themselves excellent oxidizing agents, and some of them, especially those with high oxidation states, are explosive as well. The discussion of disinfectants pertains mostly to hypochlorite, chlorine dioxide, and chlorinated aromatic compounds, especially phenols [2]. Dissolving chlorine gas in water produces hypochlorous acid $(\mathrm{HClO})$, which is stabilized as a salt with cations such as $\mathrm{Na}^{+}, \mathrm{K}^{+}$, and $\mathrm{Ca}^{2+}$.

\section{Catguts, the Gangrene of King Louie the 18th and Labar- raque's Chlorine Water}

Catguts are strings of excellent tensile strength made from processed animal intestines, which till 1900, were in use in stringed musical instruments such as violin, cello, guitar, and harp ${ }^{1}$. Catgut was used until recently on tennis and shuttle rackets and as surgical sutures by doctors. The word catgut was probably derived from cattle-gut, as it was made from the small intestines of sheep 


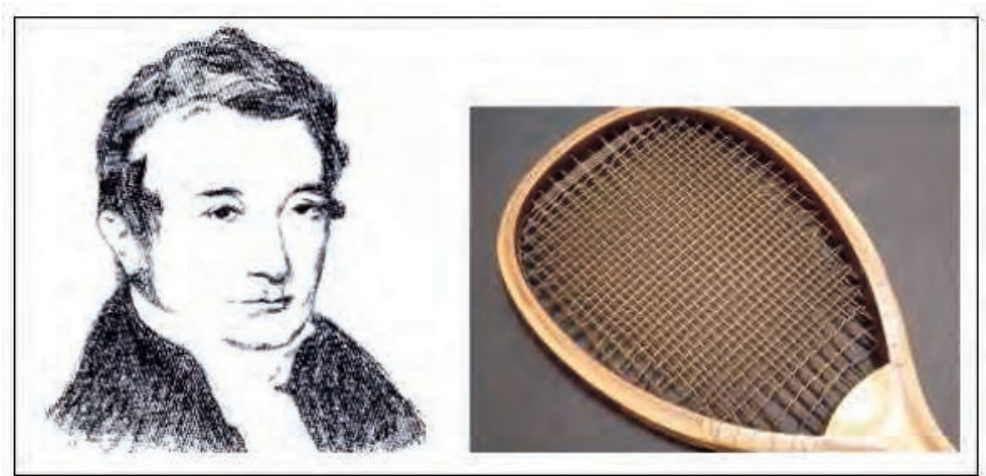

and goats. The small intestine of a sheep, when stretched, is around $25 \mathrm{~m}$ in length (unlike the human intestine, which is around $1 \mathrm{~m}$ in length), and during the 1800s, making catguts was a thriving industry. The small intestines of sheep were cleaned and treated with lye $(\mathrm{KOH})$ followed by sulfur dioxide before processing them as strings.

However, there was always putrefaction happening on such catguts resulting in awful odor and decomposition. In 1820, the French Society for Encouraging National Industry offered a prize of 1500 francs for discovering a method that could prevent the putrefaction of catguts. Antoine-Germain Labarraque, a French chemist and pharmacist, received this coveted prize as he showed that chlorinated bleaching solutions not only removed the smell of putrefaction of animal tissue decomposition, but also retarded the decomposition, thus helping the catgut industry (Figure 3). Berthelot had prepared potassium hypochlorite in 1789, and following his procedure, Labarraque prepared sodium hypochlorite by bubbling chlorine gas through a solution of sodium hydroxide in 1799. His bleaching and disinfecting solution was named Eau de Javel (Javel water) and later as Eau de Labarraque. Almost at the same time, two Scottish chemists, namely Charles Tennant and Charles Macintosh, developed a process for making calcium hypochlorite, well known as bleaching powder by the reaction of dry slaked lime, $\mathrm{Ca}(\mathrm{OH})_{2}$ with chlorine gas. Tennant received a British patent for bleaching powder in 1799. Labarraque also made chlorinated lime by dissolving bleaching powder in water
Figure 3. AntoineGermain Labarraque and catgut on an old tennis racquet (Image credit: tennishistory.com.au).

Antoine-Germain Labarraque, a French chemist and pharmacist, showed that chlorinated bleaching solutions not only removed the smell of putrefaction of animal tissue decomposition, but also retarded the decomposition, thus helping the catgut industry. 
and found this to be equally effective in preventing the putrefaction of catguts. A British chemist, Thomas Alcock (1827), in a lengthy article entitled 'An essay on the use of chlorurets of oxides of sodium and lime as powerful disinfecting agents', profusely endorses Labarraque's methods and also describes bleaching powder as a deodorant and disinfectant in the successful deodorization of an exhumed corpse died due to suspected poisoning.

King Louie XVIII of France (reinstated as the king after his brother and wife were guillotined during the French revolution), died in 1824. At that time, he was severely affected by gangrene of both his legs. During his last days, his legs were emanating foul odor due to decaying flesh, and after death, it was unbearable for those standing near the dead body. Labarraque was called in to find a way to remove the bad smell so that the king could be given a decent burial. He solved the issue by covering the dead body with a cloth soaked with his chloro-sodaic solution (sodium hypochlorite solution).

The detailed methods of preparation and usage of Labarraque's chloride of lime and chloro-sodaic solutions were made available for the public in the form of a small pamphlet in 1828 for the prevention of contagious infections, the treatment of putrefaction of septic wounds, disinfection, and deodourisation of latrines and sewers, and for use while embalming and exhumation of dead bodies.
The detailed methods of preparation and usage of Labarraque's chloride of lime and chloro-sodaic solutions were made available for the public in the form of a small pamphlet in 1828 for the prevention of contagious infections, the treatment of putrefaction of septic wounds, disinfection, and deodourisation of latrines and sewers, and for use while embalming and exhumation of dead bodies [3]. It is noteworthy that the interim guidance issued by the WHO on 15 May 2020 for cleaning and disinfection of environmental surfaces in the context of COVID-19 recommends hypochlorite-based products which include liquid sodium hypochlorite and solid calcium hypochlorite formulations which when dissolved in water provides a dilute solution in which the undissociated hypochlorous acid $(\mathrm{HClO})$ is the active compound with antimicrobial activity [4]. Many commercial, over the counter disinfectants ( such as Clorox ${ }^{\circledR}$ ) contain about $7 \%$ sodium hypochlorite as the main germ-killing ingredient. 


\section{Semmelweis and the Habit of Washing Hands by Chlorine Water by Medical Practitioners}

The Hungarian born medical practitioner Ignaz Semmelweis was known for his pioneering antiseptic procedures. He was described as the "saviour of mothers", as his disinfection methods saved the lives of many young mothers in Vienna. In 1847, Semmelweis was working at the maternity department of the Vienna General Hospital, Austria, as a supervisor. There were two obstetrical and gynecology wards in the hospital where childbirth was handled. One ward was managed by midwives and the other by medical students and doctors. An intriguing problem of those times was that many young mothers died immediately after childbirth due to an unexplained disease named puerperal fever (also known as childbed fever). As many as $30 \%$ of mothers died from this disease every month in that hospital. Known for his keen observation, Semmelweis noticed that the death of mothers due to this disease was three times more in the clinic managed by doctors and medical students than the clinic managed by the midwives! $\mathrm{He}$ also noticed that even women who gave birth at home were less affected by puerperal fever. He felt that the medical students and doctors were doing something wrong in their procedures. His keen observation led to the finding that the medical students, while attending to women giving childbirth, were also practicing their surgical skills on cadavers/dead bodies in the adjacent autopsy room. It was at this time that one of the doctors of the hospital died shortly after performing an autopsy. Semmelweis had noted that this doctor had accidentally made a small cut on his fingers during the autopsy. This incident rang alarm bells in his mind, and he felt that in the first obstetrical clinic, the doctors and medical students are probably carrying some "cadaverous particles' on their hands from the autopsy room to the examination room for patients. This also explained the much lower mortality rate in the second clinic managed by the midwives, who had no physical contact with the cadavers.

Semmelweis was aware of Labarraque and his 'chloride of lime'. $\mathrm{He}$ found a solution to the problem of maternal mortality by in-
The Hungarian born medical practitioner Ignaz Semmelweis was known for his pioneering antiseptic procedures. He was described as the "saviour of mothers", as his disinfection methods saved the lives of many young mothers in Vienna. 
Semmelweis found a solution to the problem of maternal mortality by insisting that the doctors

and medical students wash their hands and surgical instruments with a solution of the 'chloride of lime' (calcium hypochlorite solution) between autopsy work and examination of patients. sisting that the doctors and medical students wash their hands and surgical instruments with a solution of the 'chloride of lime' (calcium hypochlorite solution) between autopsy work and examination of patients. He tried this because he had observed that the chlorinated solution removed the decaying smell of infected autopsy tissue, and hoped that perhaps it can destroy the causal contaminating agent being transmitted from the cadavers. After strict implementation, he saw that this new procedure immediately reduced the incidence of fatal puerperal fever in the first clinic manned by medical students from about $30 \%$ to about $1-$ $2 \%$ and finally to $0 \%$. Semmelweis, confident with the success of his method, started advocating the use of chloride of lime or chlorine water to wash hands to prevent childbed fever and death resulting from such diseases.

However, the medical community did not respond positively to the advice of Semmelweis. His hypothesis that 'cleanliness can simply get rid of life-threatening diseases' was considered ridiculous at that period and was ignored, rejected, and subjected to mockery. This upset him further, and he was angry by the indifference shown by the doctors of that time and wrote open angry letters to many well-known European obstetricians, even calling them irresponsible murderers. He was dismissed from the hospital in Vienna and was, therefore, forced to move to Budapest, Hungary, where he worked for few years and continued his tirade against unclean practices. His contemporaries thought he was losing his mind, and in 1865, he was put in a mental asylum by his own colleagues, where he died a lonely death at the young age of 47 years [2].

It was only years after his death, when the germ theory was developed by Robert Koch and Louis Pasteur, that Semmelweis's beliefs earned respect and acceptance in scientific circles, and one could offer a theoretical explanation for his findings. He is now considered the pioneer of antiseptic procedures. The Budapest University of Medicine, where he had worked briefly as a faculty, on its 200th anniversary in 1969, was renamed as the Semmelweis University of Medicine in remembrance of this great scien- 


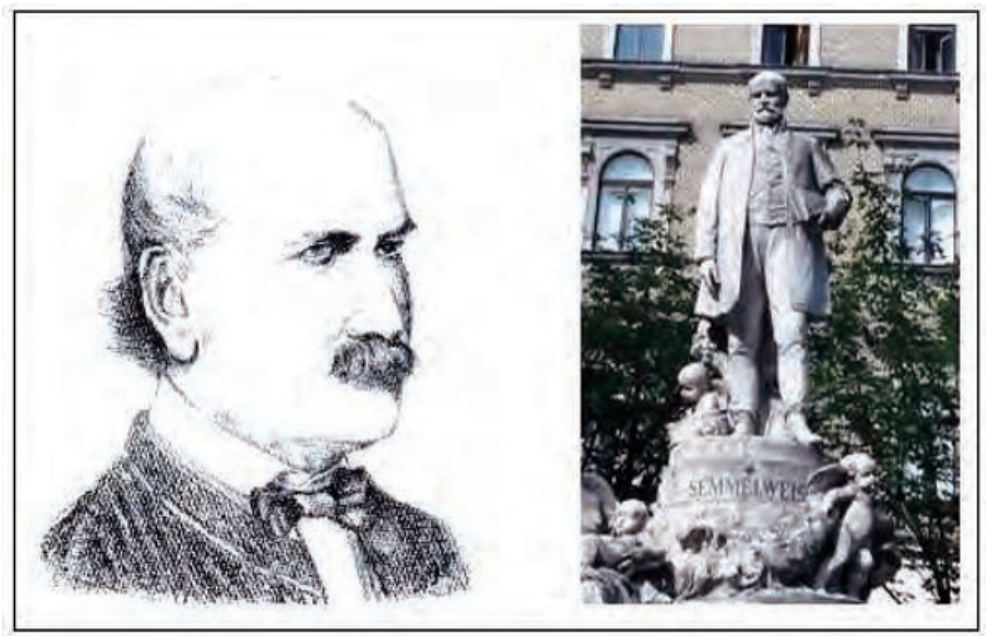

tist (Figure 4).

It is amazing to know the wide reach of hypochlorite even inside the human body as researchers from Ruhr University Bochum, Germany have observed that hypochlorite is generated by the white blood corpuscles in the fight against invading microorganisms in the blood [5]. When bacteria enter the bloodstream, white blood cells which are the first line of defense literally devour the invaders (referred to as 'phagocytosis') and shower the bacteria with a cocktail of chemicals. Minute quantities of hypochlorite and hydrogen peroxide are generated within the white blood cells which help to break the cell membrane and oxidize the bacteria. Hydrogen peroxide produced from superoxide converts chloride to hypochlorite in a myeloperoxidase-catalyzed reaction. So the chloride which we consume in the form of common salt has multiple uses in the body, not just the production of hydrochloric acid in the stomach for digestion.

\section{The Discovery of Carbolic Acid (Phenol) as a Disinfectant}

During ancient times when the oceans and seas were the battlegrounds between pirates and traders, the adventurous men were often sailing for long periods in search of unseen lands. However, the health of these sailors was often compromised. The
Figure 4. Ignaz Semmelweis and his statue in front of Szent Rokus hospital in Budapest, Hungary where he worked from 1851 to 1857 (Photograph credit: Himetop, The history of medicine topographical database).

It is amazing to know the wide reach of hypochlorite even inside the human body as researchers from Ruhr University Bochum, Germany have observed that hypochlorite is generated by the white blood corpuscles in the fight against invading microorganisms in the blood. 
2 The thick dark liquid obtained during the processing of coal while making coke and coal gas.

Pasteur had proposed three methods to eliminate microorganisms namely: (1) filtration, (2) exposure to heat, or (3) exposure to chemicals. discovery that vitamin $\mathrm{C}$ is an essential requirement to prevent the debilitating disease—scurvy —of seafarers led to the solution of canning vegetables and meat for long sea journeys. Pirates and seamen often battled, leading to injuries, and while on the sea, the only solution to a badly hurt leg or hand was amputation to prevent gangrene and infection leading to death. The most common picture of a pirate that comes to one's mind is that of a one-legged bearded man with an eye patch! A very interesting and useful observation made by seafarers of those times was that after an amputation if the stump of the amputated leg or hand is dipped immediately in molten coal $\operatorname{tar}^{2}$, the chances of healing and recovery are exceptionally better than when it is left as such. One can imagine the pain of amputation multiplied by dipping the stump in hot coal tar! But it worked like magic, and there is an interesting chemistry behind this procedure. Analysis of coal tar has indicated that some of its major ingredients are phenol and its analogs which are shown to have excellent germicidal properties, thus facilitating disinfection of the wounds and a fast recovery!

Almost $18 \%$ of coal tar consists of phenol and cresols, and phenol is a relatively inexpensive compound. Friedlieb Runge, who in 1834 extracted it from coal tar called it Karbolsaure (coal-oil acid), which later on became carbolic acid in English. In 1843 it was renamed phenol. The antiseptic property of phenol was discovered by a British surgeon Sir Joseph Lister. In those days, serious wounds would often lead to infection, followed by gangrene leading to death. The prevalent thought was that infection of wounds was due to exposure to miasma or bad air. The miasma theory proposed that epidemics were caused by the foul-smelling air emanating from decaying organic matter, and the wind carried it around, spreading the disease far and wide. This theory was replaced later by the germ theory put forth by Louis Pasteur and Robert Koch. Lister had read about the germ theory and was convinced that germs were preventing the curing of wounds. Pasteur had proposed three methods to eliminate microorganisms namely: (1) filtration, (2) exposure to heat, or (3) exposure to chemicals. The well-known technique named after him-pasteurization—is 
the exposure to heat below the boiling point of food materials such as milk, wine, and beer. Since filtration and exposure to heat could not be applied to human tissue, Lister decided to explore the chemical treatment for killing microorganisms on wounds.

Lister had read that civic authorities were treating foul-smelling sewage pools with cheaply available carbolic acid to reduce the bad smell and destroy disease-causing insects and worms which interestingly, seemed to work. Later he wrote in the British medical journal, Lancet, "In the course of the year 1864, I was much struck with an account of the remarkable effects by carbolic acid upon the sewage of the town of Carlisle-preventing all odor from the lands irrigated with the refuse material but as it was stated, destroying the entozoa which usually infest cattle fed upon such pastures" [6]. Lister decided to try carbolic acid or phenol for disinfection. In 1865, he tried using carbolic acid (phenol) on a tibia bone fracture of an eleven-year-old boy where the broken bone had pierced the skin of his lower leg. Normally in those days, amputation would have been the only solution for such a case. After setting the bone and supporting the leg with splints, Lister took a clean cotton gauze, soaked it in pure phenol, and applied it to the wound. He covered the wound and phenol gauze with a layer of tin foil and left it as such for four days. When he checked the wound later, he saw no signs of infection, only redness of the wound from mild burning by the phenol. By further application of diluted phenol-soaked bandages, the wound was completely cured in about six weeks. The method was repeated successfully for many such wounds.

Based on his success, Lister proposed in 1867 to surgeons that phenol should be rubbed on the surgical instruments, hands of surgeons, and the bandages for covering the wounds should be soaked in it. He even suggested that while the surgery is in progress, the operation theatre should be sprayed with phenol, and phenol had to be sprayed also on the surgeons, to ward off germs (Figure 5). Surprisingly, this procedure was effective as mortality rate during surgery dropped to $15 \%$, but the practice was becoming unpopular due to damage of the skin of medical practitioners and
Lister proposed in 1867 to surgeons that phenol should be rubbed on the surgical instruments, hands of surgeons, and the bandages for covering the wounds should be soaked in it. He even suggested that while the surgery is in progress, the operation theatre should be sprayed with phenol, and phenol had to be sprayed also on the surgeons, to ward off germs. 
Figure 5. Sir Joseph Lister and a depiction of surgery using phenol as disinfectant.

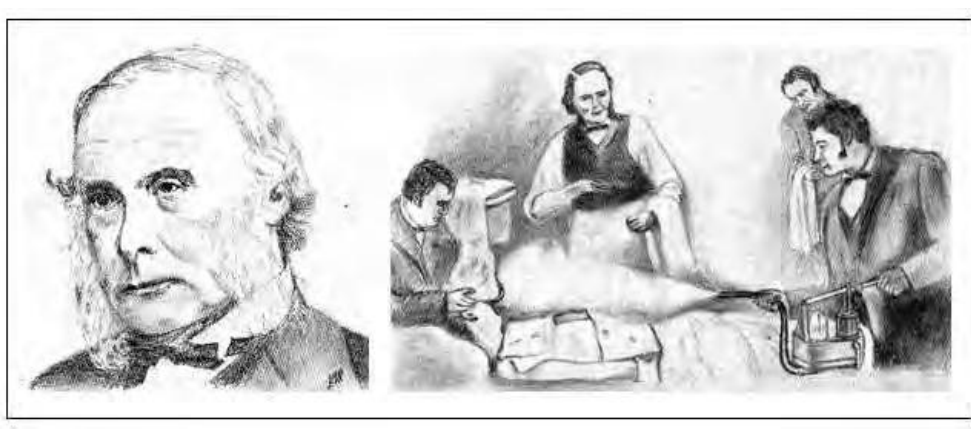

patients from continued exposure to phenol. The phenol spray during surgery was also dangerous to the mucous membrane of the lungs when inhaled by doctors and nurses. By 1890, the phenol spray was abandoned by the medical community, and the use of surgical gloves and surgical masks were initiated for use in the operation theatre.

\section{The Beginning of the Practice of Using Face Masks}

During the 1880 s, a new generation of surgeons led by Johann Mikulicz from Breslau, Poland proposed the strategy of 'asepsis', which basically was to devise methods to prevent germs from entering the wound instead of using chemicals to kill the germs present on a wound. Mikulicz, in 1897 , began the practice of using a face mask for the first time.
During the 1880s, a new generation of surgeons led by Johann Mikulicz (Jan-Mikulicz Radecki) from Breslau, Poland proposed the strategy of 'asepsis', which basically was to devise methods to prevent germs from entering the wound instead of using chemicals to kill the germs present on a wound. So now, in addition to hands and instruments, even the breath of doctors and nurses was to be suspected for germs. Mikulicz, a fine pianist and a surgeon who is well known for his pioneering surgical procedures on the digestive system, with the help of a local bacteriologist showed experimentally that respiratory droplets exhaled from the mouth indeed carried active bacteria. Mikulicz, based on these findings in 1897, began the practice of using a face mask for the first time. Mikulicz described his face mask as "a piece of gauze tied by two strings to the cap, and sweeping across the face so as to cover the nose and mouth and beard" (Figure 6) [7]. This method of controlling the infection that gave importance to keeping the germs away as opposed to destroying them with chemicals was taken up by doctors elsewhere in Europe. However, some of them also ridiculed this new practice. For example, the German physician 


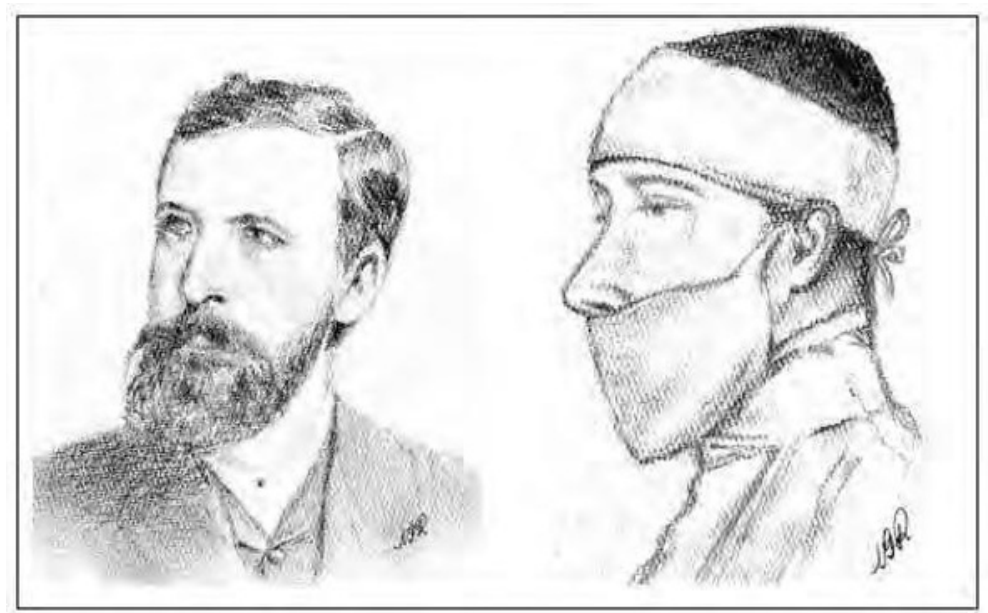

Alexander Fraenkel from Berlin sarcastically commented about the "whole surgical costume with a bonnet, mouth mask, and veil, devised under the slogan of total wound sterility" [7]. However, masks became increasingly widespread, and by 1935 most of the medical fraternity were using masks in operating theatres across Europe and the USA. Incidentally, Mikulickz was also the first to use surgical gloves during operations.

The face mask as a means to protect doctors, nurses, and patients from infectious diseases was practiced during the Manchurian plague of 1910-11 and the Spanish influenza pandemic of 191819. During the Spanish influenza pandemic and afterward, the practice of wearing masks moved beyond the operating theatre and to the public for protecting the wearer from infection. During the current times of COVID, the whole world is back to using masks of all kinds, and after 100 years, the practice of wearing masks is still extremely beneficial.

\section{Dettol and the Fine-tuning of Carbolic Acid by Chlorina- tion}

Encouraged by the success of phenol as a disinfectant, chemists of those times explored the possibility of making phenol derivatives that could work as disinfectants and at the same time did
Figure 6. Johann Mikulicz and model of the earliest face masks used.

The face mask as a means to protect doctors, nurses, and patients from infectious diseases was practiced during the Manchurian plague of 1910-11 and the Spanish influenza pandemic of 1918-19. During the Spanish influenza pandemic and afterward, the practice of wearing masks moved beyond the operating theatre and to the public for protecting the wearer from infection. 
not have the skin corrosive or skin-irritating properties of phenol. The original formulation of Lysol introduced in 1889 in Germany to fight cholera had cresols (methyl phenols) as the active ingredient. It was Paul Ehrlich, well known for his discovery of 'Salvarsan' for the treatment of the sexually transmitted disease, Syphilis in 1909 who took the first step forward. By that time it was known that both chlorine and phenol can work as disinfectants, and Ehrlich decided to combine the properties of both. A series of chlorinated phenols were made whose disinfectant properties were explored against different bacterial strains. These were found to be good as disinfectants, and compounds with alkyl groups on the aryl ring were found to be even better. The best among the lot turned out to be 4-chloro-3, 5dimethylphenol [para-chloro-meta-xylenol (PCMX)]. PCMX has been reported to be developed in Germany in 1927, but its disinfectant activity was examined only in 1933 by the makers of Dettol [8].

The disinfectant/antiseptic with the brand name Dettol is currently the number one disinfectant and handwash in the world. As given on the website of its British origin manufacturer

Reckitt Benckiser, it is currently available in 124 countries globally and is used by 2 billion people every day.
The disinfectant/antiseptic with the brand name Dettol is currently the number one disinfectant and handwash in the world. As given on the website of its British origin manufacturer Reckitt Benckiser, it is currently available in 124 countries globally and is used by 2 billion people every day. The company had an income of around 1300 crore British pounds in 2019. According to Reckitt Benckiser's website, since its invention in 1933, Dettol has been used by doctors in hospitals to disinfect hands, especially while delivering babies. The earliest reference to Dettol is found in an article entitled 'Antisepsis in midwifery', by Colebrook and Maxted in the Journal of Obstetrics and Gynaecology published in 1933 [9]. In this work, the activity of few disinfectants of those times such as Lysol, iodine, soap, and Dettol against the bacteria Streptococcus progenes is described. In those days, a major reason for maternal deaths was the entry of streptococci in the genital tract of women during child labor followed by infection. This study revealed that both Dettol (30\%) and iodine (aqueous with KI) eliminated streptococci. However, iodine being unsuitable for frequent application on the skin, Dettol was 
recommended as the best antiseptic for disinfection.

The paper described Dettol as the proprietary name given to a halogen derivative of xylenol, the germicidal properties of which have been studied by Dr W C Reynolds, Research Chemist to Messrs' Reckitt, of Hull, England, the firm that marketed Dettol. The xylenol derivative which later on was revealed as 4-chloro3, 5-dimethylphenol (para-chloro-meta-xylenol) is by itself not soluble in water, but in Dettol, it is dissolved in a mixture of pine oil (alpha-terpineol) and castor oil, which contains ricinoleic acid. This solution is miscible with water in a permanently stable white emulsion (made possible by micelles formed by the ricinoleic acid) with the pleasant smell of pine oil. Unlike many other antiseptic substances commonly used, the dispersal of Dettol solution in concentrated form on the skin or mucous membranes does not lead to any dangerous effects. To test this, the undiluted solution of Dettol was rubbed on the hands of 20 healthy adults daily for 15 days. The hands were left unwashed for a minimum period of one hour, and it was observed that it caused no skin irritation. Undiluted Dettol solution was also applied to freshly scratched skin, and the vaginal mucous membrane and no irritant effects were observed [9]. Another research work by Prof. Bernhard Zondek, published in the journal Nature in 1942, also refers to Dettol and concludes that treatment with halogenated phenols, especially Dettol is harmless in man with no secondary effects [10]. It may be noted that the relatively new product, Dettol liquid handwash, does not contain PCMX; it is mostly soap with an antibacterial preservative methylchloroisothiazolinone.

The antiseptic ingredient present in the Dettol disinfectant solution is $4.8 \%$ para-chloro-meta xylenol (PCMX), and it comes from the phenol family of disinfectants. Any chemist who had handled pure phenol knows that if a drop of phenol accidentally falls on the hand or fingers, it burns the skin, which later peels off. The major hazard of pure phenol is its ability to penetrate the skin rapidly, causing severe burns, which can be even fatal if large areas of skin are affected. Due to its local anesthetizing properties, skin burns can be painless too. In total contrast, Dettol, even

4-chloro-3, 5-dimethylphenol (parachloro-meta-xylenol) is by itself not soluble in water, but in Dettol, it is dissolved in a mixture of pine oil (alpha-terpineol) and castor oil, which contains ricinoleic acid. This solution is miscible with water in a permanently stable white emulsion (made possible by micelles formed by the ricinoleic acid) with the pleasant smell of pine oil. 
Figure 7. Comparison of $\mathrm{pKa}$ values of phenol and substituted phenols.
Lysol, known from 1889 , is the brand name of the number one disinfectant in the USA, which unlike Dettol, has only in the recent past entered south Asian markets such as India. Known even before Dettol was invented, it nowadays makes use of many compounds with disinfecting properties such as ethanol, isopropanol, and hydrogen peroxide in its formulations.

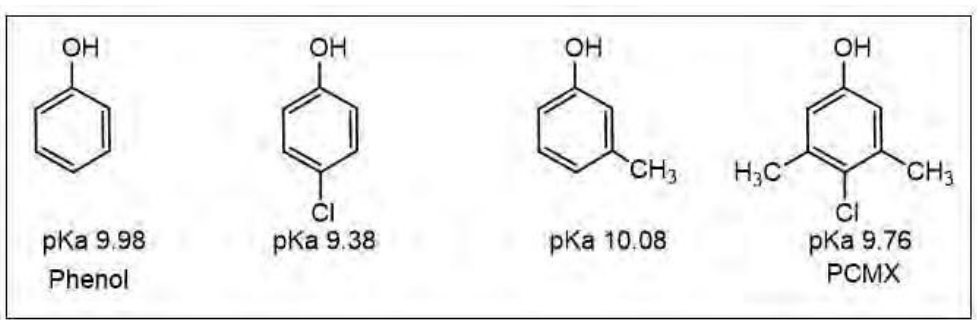

in the undiluted form, does not affect even freshly scratched skin, but at the same time is a more powerful disinfectant.

The differences between phenol and PCMX are many. Phenol has a solubility in water of $8.3 \mathrm{wt} \%$ while that of PCMX is $0.03 \mathrm{wt} \%$ as increased substitution, especially by methyl groups, makes the latter less water-soluble. As shown, the pKa of phenol is 9.98, while that of PCMX is 9.76 (Figure 7). So PCMX is slightly more acidic than phenol, which means that a much lower concentration of the disinfectant can be effective with lesser toxicity and fewer side effects. In the formulation, pine oil is present, and PCMX is highly soluble in the same. Ricinoleic acid is used, which forms micelles, and when distributed in water, it forms a suspension where the PCMX is partly inside the droplets of pine oil. There is an equilibrium between PCMX present inside the micelles, and that is dissolved in water. When the PCMX present in the aqueous phase is used up, more are released from the droplets of pine oil. The lower concentration and poor water solubility make PCMX less sensitive to the skin compared to pure phenol [11].

\section{Benzalkonium Chloride-The Effective Disinfectant in Lysol}

Lysol, known from 1889, is the brand name of the number one disinfectant in the USA, which unlike Dettol, has only in the recent past entered south Asian markets such as India. Known even before Dettol was invented, it nowadays makes use of many compounds with disinfecting properties such as ethanol, isopropanol, and hydrogen peroxide in its formulations. Currently, the major disinfectant compound in their formulations is benzalkonium chloride (Figure 8). Formulations of Lysol before 1953 were said 


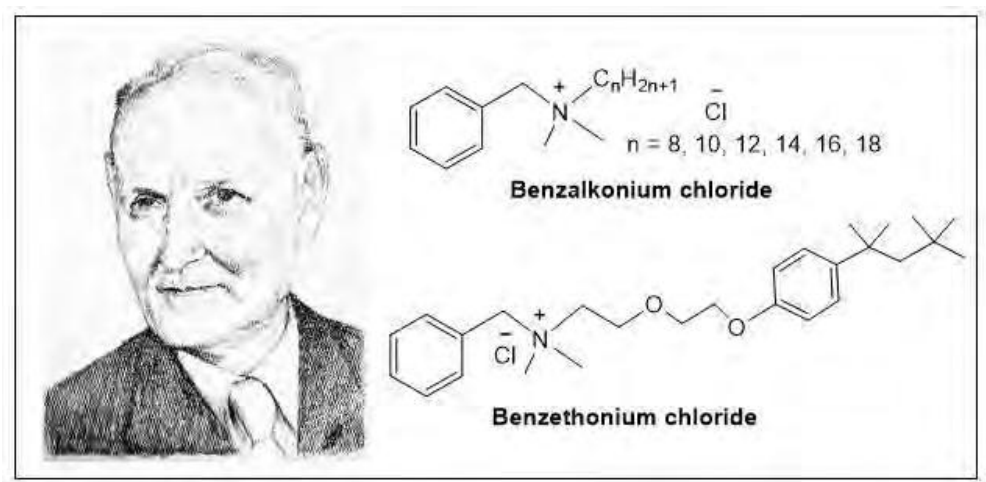

to have phenolic compounds such as cresol (3-methylphenol) as active ingredient, which has since then been discontinued due to complications. However, the introduction of benzalkonium chloride as the major disinfecting component of Lysol was a welcome change.

The disinfection property of benzalkonium chloride was observed for the first time in 1935 by the German pathologist and bacteriologist Gerhard Johannes Paul Domagk who, interestingly, received the Nobel Prize for another path-breaking discovery, that of Prontosil, the first bacteriostatic sulfa drug (Figure 8). In a paper published in the journal Deutsche Medizinische Wochenschrift in 1935 entitled 'A new class of disinfection material' Domagk introduced the benzalkonium chloride to the general public [12]. The formulation, named Zephirol, was an aqueous solution of high molecular weight alkyldimethyl benzyl ammonium chlorides having a long alkyl chain. This compound is similar to the soap or detergent in having a long chain aliphatic group.

Unlike soaps and detergents which at the other end of the chain have anionic units (carboxylate or sulfonate), benzalkonium chloride has a cationic trialkyl benzylammonium unit with a chloride counter-ion. This class of cationic detergents with varying chain lengths in one of the alkyl units has some very useful properties such a neutral $\mathrm{pH}$, low surface tension, and good wettability. It also has high chemical stability, little or no toxicity, and does not irritate the skin. The compound has strong and rapid germicidal activity and is a highly efficient germicide for the skin. It should
Figure 8. Gerhard Domagk who discovered the disinfection properties of benzalkonium chloride.

The disinfection property of benzalkonium chloride was observed for the first time in 1935 by the German pathologist and bacteriologist Gerhard Johannes Paul Domagk who, interestingly, received the Nobel Prize for another path-breaking discovery, that of Prontosil, the first bacteriostatic sulfa drug. 
be mentioned that the role of chlorine in this compound is incidental only as during the synthesis, benzyl chloride is the reagent used for the preparation of the ammonium salt.

Benzethonium chloride is a closely related trialkylammonium chloride, which is a water-soluble powdery solid with a melting point of $163^{\circ} \mathrm{C}$. This compound is used as an ingredient in liquid hand soaps like Dial, mouthwashes, first-aid antiseptics, and antibacterial moist towels.

Figure 9. Chlorhexidine digluconate.
Benzethonium chloride is a closely related trialkylammonium chloride, which is a water-soluble powdery solid with a melting point of $163^{\circ} \mathrm{C}$. This compound is used as an ingredient in liquid hand soaps like Dial, mouthwashes, first-aid antiseptics, and antibacterial moist towels.

\section{Chlorhexidine-The Bi-guanidine Present in Savlon and Mouthwashes}

A more recent entry in the field of disinfectants and antiseptics is chlorhexidine (1, 6-bis-( 4 ' chlorophenyl bigaunido)hexane, which was discovered in 1954 by a team of scientists from Imperial Chemical Industries of England and is now widely used in many personal hygiene items such as mouthwashes, toothpastes, and hand washes [13].

It is a bisguanide that has two p-chloroguanide units linked by a hexamethylene chain. The team led by G W Davies of ICI England zeroed in on this molecule after trying out the antibacterial properties of analogous compounds having varying chain length and the nature of substituents on the aryl ring. The compound is exclusively used in Savlon brand products, often mixed with the trialkyl ammonium compound, cetrimide, and the brand name 'Savlon' is derived from Avlon works near Bristol, UK, where ICI manufactured the compound initially. It is a strong base and

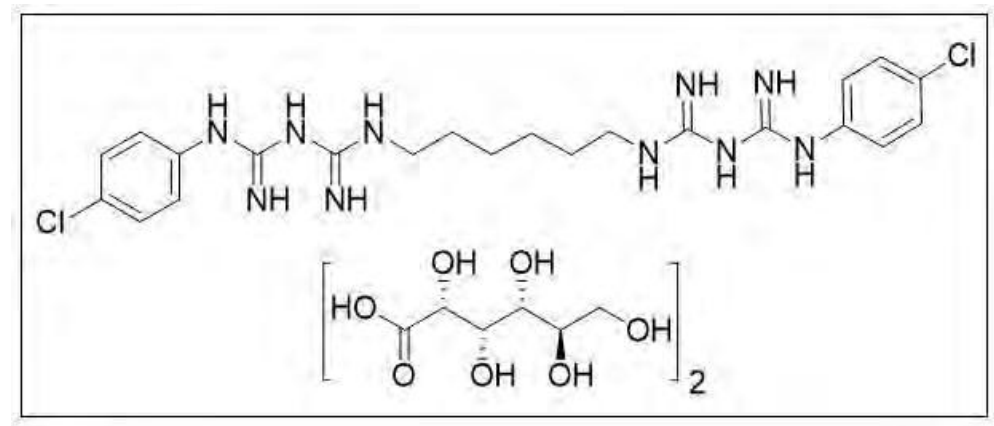


at physiological $\mathrm{pH}$ becomes a dication. It is insoluble in water and, therefore, is formulated along with gluconic acid or acetic acid to form water-soluble digluconate or diacetate (Figure 9). This formulation is the most preferred one for mouthwashes and toothpastes as it has very low oral toxicity, is odorless, and even if ingested (which is unlikely due to the extremely bitter taste), it is well-tolerated as only negligible systemic absorption takes place except when large doses are consumed. Chlorhexidine is found to retain its antimicrobial activity in the presence of blood and other body fluids.

\section{Mode of Action of Chlorine Based Disinfectants}

During the period 1918 to 1944 , it was believed that $\mathrm{HClO}$ decomposes to give $\mathrm{HCl}$ and a monoatomic radical species, which was termed nascent oxygen. The general belief was that the nascent oxygen $[\mathrm{O}]$ was responsible for the inactivation of microbes and not chlorine or HClO. Though the proposal was not supported by any experimental evidence, many scientists of the time accepted it. A 1944 publication by S L Chang changed this common belief. Chang tried to inactivate the cysts of Entamoeba histolytica ${ }^{3}$ with high concentrations of hydrogen peroxide $(3000 \mathrm{mg} / \mathrm{l})$ which is expected to have 1500 times more nascent oxygen than $\mathrm{HClO}$. In his report, he noted that there was no destruction or inactivation of the cysts with peroxide. In contrast, a reaction with chlorine water inactivated the cysts. Chang reported in his paper, "The action of chlorine and chloramine compounds on cysts was attributed to the active chlorine which may oxidize or chlorinate the proteins in the protoplasm. The possibility of action by nascent oxygen liberated by $\mathrm{HOCl}$ was indirectly studied, and the evidence strongly indicated that this was unlikely to occur." [14].

Hypochlorous acid has been observed to react with the DNA and RNA, the unsaturated bonds of lipids and sulfhydryl (SH), and the amino group side chains of proteins. Based on experimental evidence, the mode of inactivation and destruction of microorganisms by chlorine and hypochlorite can be attributed to three

\footnotetext{
${ }^{3}$ The intestinal parasite which causes amoebiasis.
}

Hypochlorous acid has been observed to react with the DNA and RNA, the unsaturated bonds of lipids and sulfhydryl (SH), and the amino group side chains of proteins. 
GENERAL ARTICLE

Figure 10. Possible modes of action of different disinfectants on the bacterial cell.
Phenol, chlorinated phenols, and PCMX have been found to bind to the proteins present on the cell membrane of bacteria through the phenolic $\mathrm{OH}$ group, which disrupts the cell membrane and results in the contents of the bacterial cell to leak out.

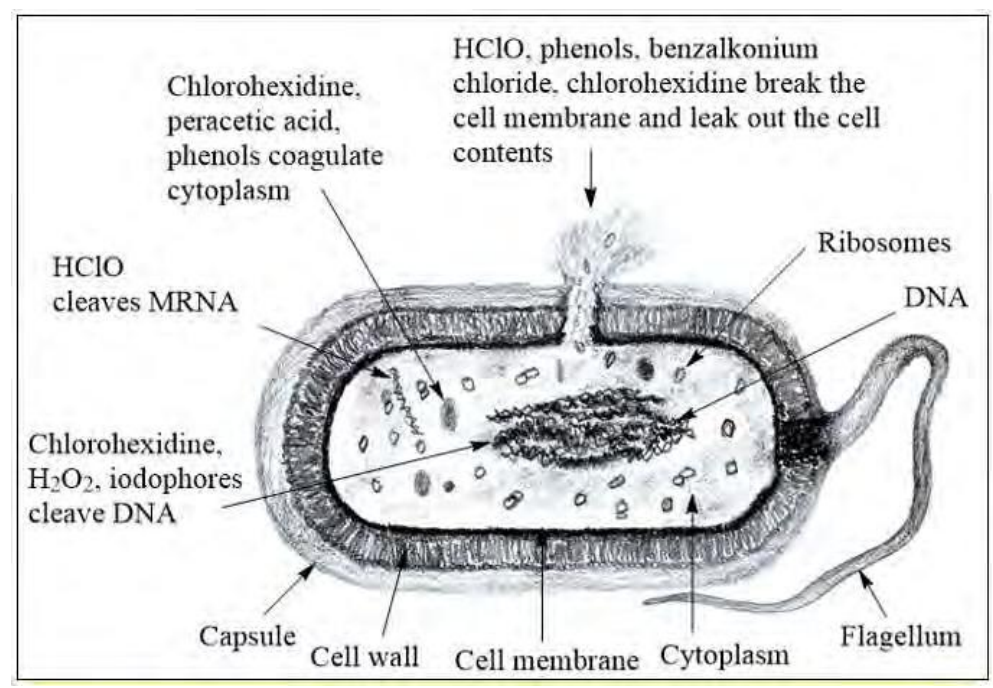

major reasons. These are (i) interference in the functions of the cell membrane: permeability of the bacterial cell membrane getting affected by chlorination of the membrane, which results in the leakage of the components of the cell, (ii) loss of activity of the enzymes in the cell as the ionic environment of the cell gets modified, and (iii) by irreversible oxidation of sulfhydryl groups of the proteins which affects the enzyme and protein functions of the microorganisms [2].

Phenol, chlorinated phenols, and PCMX have been found to bind to the proteins present on the cell membrane of bacteria through the phenolic $\mathrm{OH}$ group, which disrupts the cell membrane and results in the contents of the bacterial cell to leak out (Figure 10). Once the cell membrane is broken, more phenol units enter the cell, binding further with proteins and enzymes and shutting down the cell function. At higher concentrations, coagulation of the proteins and nucleic acids is likely to take place.

Quaternary ammonium compounds such as cetyl trimethyl ammonium bromide (cetrimide) are well-known surfactants and membraneactive agents. Benzalkonium chloride also works similarly and attacks the cytoplasmic membrane of bacteria or the plasma membrane of yeasts. The following sequence of events were proposed as happening to microorganisms when they are exposed 
to cationic agents: Initially, the adsorption and penetration of the agent onto the cell membrane takes place. This is followed by the reaction with the cytoplasmic membrane (lipid or protein), which results in the disorganization of the membrane. Following this, leakage of intracellular low-molecular-weight materials takes place. Further, degradation of proteins and nucleic acids and wall lysis are caused by autolytic enzymes. Thus, there is a loss of structural organization and integrity of the cytoplasmic membrane in bacteria [15].

At bacteriostatic concentrations, chlorhexidine has been found to get adsorbed onto the phosphate-containing protein components in the bacterial cytoplasmic membrane, resulting in the leakage of cytoplasmic components. At higher concentrations, the compound has been found to form irreversible precipitates with the ATP and nucleic acids present in the cell after entering the cytoplasm through the damaged cytoplasmic membrane.

\section{Can We Say That "All Is Well" With Chlorine Based Dis- infectants?}

The answer to the above query is an emphatic "No"! In the early 20th century, there was a rush to make chlorine-based pesticides and disinfectants following the success of DDT and Dettol. It is true that some of these compounds proved extremely useful and stood the test of time, as mentioned in this article. However, there were many examples of compounds that were found to have excellent activity and were aggressively marketed but had to be withdrawn later due to complications, either harmful side effects, or environmental compatibility issues. Many were also taken off the market due to strict regulations from the Food and Drug Administration, USA. The issues with such disinfectants have similarities to the story of DDT, a chlorinated pesticide. Developed in 1939, its maker received the Nobel Prize, and the compound distinguished itself during the Second World War, causing an end to malaria spreading mosquitoes in the South Pacific islands. However, once it was used indiscriminately and in exces-
In the early 20th century, there was a rush to make chlorine-based pesticides and disinfectants following the success of DDT and Dettol. It is true that some of these compounds proved extremely useful and stood the test of time, as mentioned in this article. However, there were many examples of compounds that were found to have excellent activity and were aggressively marketed but had to be withdrawn later due to complications, either harmful side effects, or environmental compatibility issues. 
Figure 11. Banned chlorine based disinfectants.

A large number of aryl polychlorinated compounds like DDT are persistent organic pollutants (POPs) as they resist degradation and persist in the environment. Their presence is detected in the groundwater

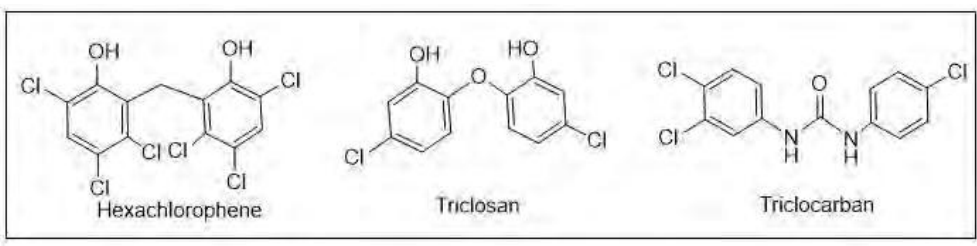

sive amounts, it began to seriously affect the balance of nature, unscrupulously killing a very large number of good insects, small birds, and animals. It was the courageous effort of one single person, Ms. Rachel Carson, and her book The Silent Spring, which made the US government ban the use of DDT. The birth of an area of chemistry namely environmental chemistry began with this incident. DDT, along with BHC and many other chlorinated pesticides have since then been replaced by more environmentally friendly and non-persistent phosphorus-based pesticides.

In general, a large number of aryl polychlorinated compounds like DDT are persistent organic pollutants (POPs) as they resist degradation and persist in the environment. Their presence is detected in the groundwater. Following the success of PCMX, the ingredient in Dettol, many new multi-chlorinated compounds, especially phenols, were made and used in toiletries and disinfectants. Three well-known examples are triclosan, triclocarban, and hexachlorophene (Figure 11). During the 1960s, two commercial formulations involving hexachlorophene were available as over-the-counter antibacterial skin cleansers in the USA, especially for the treatment of acne. Triclosan, with excellent antibacterial properties, had been a very commonly used ingredient in many personal care products such as cosmetics, hand-soaps, body washes, etc. Recent research has raised concerns that triclosan may be altering hormone regulation in animals, assisting in the development of antibiotic-resistant germs, and possibly has negative effects on immunity and fertility. Triclocarban since the 1960s has been used as an antimicrobial and antifungal compound. It also has been an ingredient in antimicrobial soaps, lotions, deodorants, toothpaste, and some plastics. Although triclocarban has very low chemical toxicity, it has been suspected to cause endocrine disruption. A rough estimate says that in 2005 
about $80 \%$ of all antimicrobial bar soaps sold in the USA contained triclocarban. In the US alone, in 2011, consumers were spending close to a billion dollars per year on products containing triclocarban and triclosan.

The first to be banned was hexachlorophene, as in 1972, a brand of baby powder made and marketed in France called Bebe which had $6 \%$ hexachlorophene killed 39 babies in France and damaged the central nervous system of several hundred babies. This led to the immediate ban of this compound all over the world. In 2013, the US Food and Drug Administration (FDA) required all companies to prove within a year that triclocarban is not harmful to consumers. In September 2016, the FDA issued a ban on nineteen consumer antiseptic ingredients which included triclosan, triclocarban, hexachlorophene, phenol, and iodine-povidone, citing questions about the safety of these antibacterials for long-term use. FDA asked their manufacturers to prove that their effectiveness is better than plain soap and water, and companies failed to provide evidence that these compounds are safe.

However, the FDA deferred from the final decision for three active ingredients, namely, PCMX, benzalkonium chloride, and benzethonium chloride, to allow more time for sponsors of these compounds who proposed to complete the studies necessary to fill the safety and effectiveness data gaps identified for these compounds. These deferrals were for one year initially and subject to renewal if adequate progress was made in filling the data gaps. Chlorhexidine also continues to be used as it is a British product, and also is not present in the list of the nineteen banned compounds by the FDA.

Table 1 consolidates the chronological development of major disinfectants and their current status where chlorine-based disinfectants are compared with other major disinfectants. While the future of many aryl chlorinated disinfectants hangs in balance due to strict environmental safety issues and regulations, the original hypochlorites of sodium and calcium continues to be used in full steam, possibly because the side product it leaves behind after performing its activity is simply chloride, which is an envi-
A rough estimate says that in 2005 about $80 \%$ of all antimicrobial bar soaps sold in the USA contained triclocarban. In the US alone, in 2011, consumers were spending close to a billion dollars per year on products containing triclocarban and triclosan. 


\begin{tabular}{|l|l|l|}
\hline $\begin{array}{l}\text { Year of } \\
\text { introduction }\end{array}$ & Disinfectant & Properties/Current Status \\
\hline $\mathbf{1 7 6 3}$ & Alcohol & $\begin{array}{l}\text { Ethyl and isopropyl alchols (60-70\%) are the main } \\
\text { antimicrobial ingredient in most hand sanitizers. }\end{array}$ \\
\hline $\mathbf{1 7 9 9}$ & $\begin{array}{l}\text { Sodium hypochlorite } \\
\text { (Detergent bleach) }\end{array}$ & $\begin{array}{l}\text { Liquid disinfectant in many commercial products e.g. } \\
\text { Clorox }{ }^{\circledR} \text {. Broad spectrum antimicrobial. WHO } \\
\text { recommended for Covid-19 related disinfection. }\end{array}$ \\
\hline $\mathbf{1 7 9 9}$ & $\begin{array}{l}\text { Calcium hypochlorite } \\
\text { (Bleaching Powder) }\end{array}$ & $\begin{array}{l}\text { Solid or powdered forumulation; } \text { WHO recommended } \\
\text { for Covid-19 related disinfection. }\end{array}$ \\
\hline $\mathbf{1 8 3 9}$ & Iodine & $\begin{array}{l}\text { Tincture of iodine (5\% solution in alcohol) and } \\
\text { iodophores (complexes of iodine with soluble polymers) } \\
\text { are still in use. }\end{array}$ \\
\hline $\mathbf{1 8 6 5}$ & Phenol & $\begin{array}{l}\text { Mixture of alkyl phenols used as heavy duty } \\
\text { inexpensive disinfectants blended with soap base. } \\
\text { Pure phenol is corrosive to skin. }\end{array}$ \\
\hline $\mathbf{1 8 9 1}$ & $\begin{array}{l}\text { Hydrogen } \\
\text { peroxide }\end{array}$ & $\begin{array}{l}\text { Used generally in dilute form (3\%). A 2\% solution with } \\
\text { surfactants, wetting agents and chelators (Accelerated } \\
\text { hydrogen peroxide }\end{array}$ \\
\hline $\mathbf{1 8 8 9}$ has increased germicidal activity.
\end{tabular}

Table 1. Chronological development of major disinfectants and their current status. ronmentally safe, earth and sea abundant anion. Incidentally, it is from this 'salt of the earth' — sodium chloride — that the chemistry and the story of chlorinated disinfectants began with the reaction of table salt with sulfuric acid to form hydrochloric acid. 


\section{Summary}

The history, development, and current status of the most widely used chlorine-based disinfectants are described in the article. The possible mode of action of different types of disinfectants and their future sustainability, especially from the perspective of environmental safety, is also evaluated.

\section{Acknowledgements}

A J Elias thanks DST SERB, India for their sanction of the research grant [CRG 2019/000013]. The article is published as a requirement of scientific social responsibility policy under this DST SERB project fund. Thanks are due to N D Reddy for the artwork given in this article.

\section{Suggested Reading}

[1] S Hazra, et.al., Table salt as a catalyst for the oxidation of aromatic alcohols and amines to acids and imines in aqueous medium: effectively carrying out oxidation reactions in sea water, Green Chem., Vol.21, pp. 1929-1934, 2019.

[2] A J Elias, The Chemistry of the p-block Elements, Syntheses, Reactions and Applications, Universities Press, Hyderabad, 2018.

[3] A G Labarraque, On the Disinfectant Properties of Labarraque's Preparations of Chlorine, Scott James (transl), Published by S Highley, 1828.

[4] Cleaning and disinfection of environmental surfaces in the context of COVID19, COVID-19: Infection Prevention and Control, WHO guidelines 2020 WHO/2019-nCoV/Disinfection/2020.1, 16 May 2020.

[5] A Degrossoli, et.al., Neutrophil-generated HOCl leads to non-specific thiol oxidation in phagocytized bacteria, eLife, 2018; 7 DOI: 10.7554/eLife.32288.

[6] J Lister, On a new method of treating compound fracture, abscess, etc., with observations on the conditions of suppuration, The Lancet, Vol.89, pp.326-329, 1897, doi:10.1016/S0140-6736(02)51192-2.

[7] B J Strasser and T Schlich, The art of medicine: A history of the medical mask and the rise of throwaway culture, The Lancet, Vol.396, pp.19-20, 2020.

[8] E Larson and G H Talbot, An approach for selection of healthcare personnel hand wash agents, Infection Control, Vol.7, pp.419-424, 1986.

[9] L Colebrook and W R Maxted, Antisepsis in midwifery, Journ. Obstet. and Gynaecol., Brit. Emp., October, pp.966-990, 1933.

[10] B Zondek, Chemotherapeutical use of halogenated phenols as external disinfectants, Nature, Vol.149, pp.334-335, 1942.

[11] Chemistry in the cupboard: Dettol, Royal Society of chemistry, 2010. 


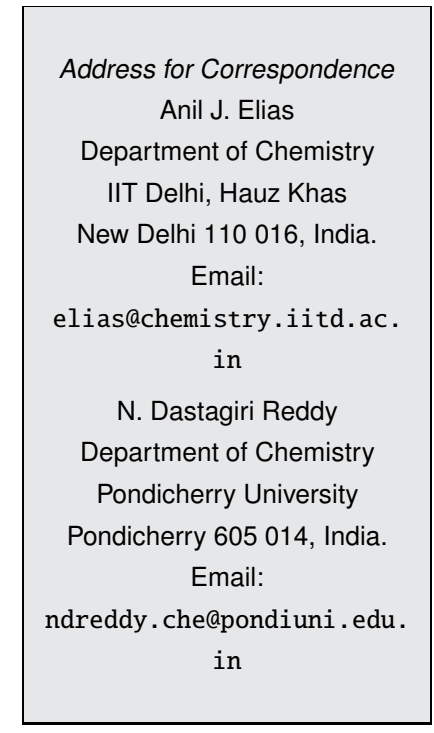

[12] G Domagk, Eine neue Klasse von Desinfectionsmitteln, Deutsche Med. Wochnschr., Vol.21, pp.829, 1935.

[13] G E Davies, J Francis, A R Martin, F L Rose, G Swain, 1, 6,- Di - 4' chlorophenyldiguanidohexane (Hibitane*). Laboratory investigation of a new antibacterial agent of high potency, Brit. J. Pharmacol., Vol.9, pp.192-196, 1954.

[14] S L Chang, Destruction of micro-organisms, Journal AWWA, Vol.36, pp.1192, 1944.

[15] G McDonnell, A D Russel, Antiseptics and disinfectants: Activity, action, resistance, Clin. Microbiol. Rev., Vol.12, pp.147-179, 1999.

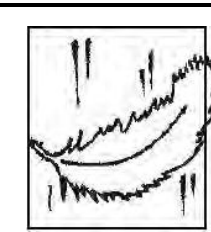

\section{Interesting Fact: Alcohol and Disinfection}

Interestingly, alcohol, which is the primary ingredient in hand sanitizers (ethyl and isopropyl alcohols; above 60\%) was one of the earliest disinfectants used during wound cleaning and surgical procedures. An alcohol swab is commonly used while blood samples are collected from fingertips or hands. Although wine was used liberally in history for wound healing, it has very low alcohol content to be an effective disinfectant. Guy de Chauliac, a surgeon of the middle ages and physician to three Popes is believed to have used 'brandy' for dressing wounds in 1363. Alcohol was regularly made available to surgeons in Paris for dressing wounds by 1763 . Auguste Nelaton, the personal surgeon of the Napoleon family in 1867, poured around a liter of 56\% camphorated ethanol into deep wounds making his patients highly intoxicated and relaxed! He was able to successfully reduce the infection of wounds by this method. 